\title{
THE INVISIBLE GENERATION': QUESTIONING AGEISM, CHALLENGING MYTHS, REFASHIONING SELVES
}

\author{
Alka Singh* \\ Vasanta College for Women, Rajghat Fort, Varanasi, India
}

\begin{abstract}
The old age is perceived as a foreign body, said Simone de Beauvoir in her essay The Coming of Age (1970). Influenced by Sartre's existentialism she emphasized the idea that the subject sees old age through the perception of others. It is a twin process of objectification: the look of others who sees female body as an object of hostility and also a woman's image of herself who feels that the body is different from her. Jeannette King calls women who are over fifty "the invisible generation" in her book Discourses on Ageing in Fiction and Feminism: The Invisible Woman (2012). She asserts that woman loses her identity after fifty because a woman's value has historically been determined by her reproductive ability, her beauty and sexuality. Gullette points out the absence of a discourse on ageism in feminism scholarship. The present paper explores the grounds of marginalization of ageing women in the Indian context from cultural and feminist standpoints and the paper aims to make ageing women visible in the literary and feminist discourses with special reference to four contemporary plays: Mangalam by Polie Sengupta, Harvest by Manjula Padmanabhan, Tripurari Sharma's Bahu and Aurat by Rasheed Jahan.
\end{abstract}

Keywords: Ageism, body, beauty myth

\section{Introduction}

Feminist movement expresses concerns for woman's human rights and works incessantly to empower the female folk. Feminist literary critics like Elaine Showalter, Virginia Woolf, Bell hooks and many other feminist critics have written against the negative portrayal of woman. Feminist scholars also tend to focus on gender and sexuality intersected with race and class concerns. It is a fact that woman's issues cannot be homogenized and simply put into a single category called 'woman's' or 'gender-based', especially in the Indian context. Yet 'ageism' was recognized quite late as an issue under feminist discourse. In her semi-autobiographical book Getting There, Manjula Padmanabhan, one of the major Indian English playwrights, wrote, "At eighteen feminism caught up with me.... It gave me a sense of community and purpose. It gave me a point of view and a vocabulary of complaint. It empowered me to buy my own contact lenses. . . But for all that it did for me, feminism could not give me a reason to live beyond thirty" (Padmanabhan, 2000, p.64). Feminists had long been silent towards the questions of 'gendered ageism', about 'how to live beyond thirty'. While looking out the reason for feminism's ageist slant Safa Samiezade'-yazd identified three major reasons as she wrote that one stems back to the women's liberation movement of the 1960s, which was dominated by younger women. "Right there, feminism was portrayed as a young woman's expression, and the movement rode with that, creating a sisterhood that completely left out mothers and grandmothers" (Samiezade'-yazd, 2010). Secondly, she recognized that feminism has been devoted to women's rights related to their reproductive health, role of mothering, sexuality and body. "This brought more attention to young women, because older women have a timestamp; once they hit menopause, it's assumed that reproduction is no longer a concern for them" (Samiezade'-yazd, 2010). The third, she identified, stems from feminism's goal of female independence over interdependence that obstructs feminism to accept ageism as a mainstream feminist issue. "Ageism' describes culturally prescribed sets of norms and prejudices about people and behavior at various stages in the life course" (Mowl, 2000, p.190) and old age is one of the most stigmatized stages of life. 
Significantly Simone de Beauvoir is one of first few feminists who raised the issue of ageism. Like 'gender', 'age' is also a cultural construct. The old age is perceived as a foreign body, said Simone de Beauvoir in her essay The Coming of Age. Influenced by Sartre's existentialism she emphasized the idea that the subject sees old age through the perception of others. It is a twin process of objectification: the look of others who sees female body as an object of hostility and also a woman's image of herself who feels that the body is different from her. Hockey and James said, "Although ageing can only take place at the site of body, embodiment necessarily brings with it the social experience of ageing" (Moore, 2009, p.656). It is a fact that age imposes certain limits on the body like limited mobility, the vulnerability to illness, the increasing unreliability of the senses and memory (Waxman, 1997, p.8) but the issue of woman's ageing is much stigmatized as far as their literary portrayal is concerned. 'Age' is not only bodily but "socially, historically and culturally specific" (Moore, 2009, p.656). Along with gender discrimination, age discrimination is too stereotyped making older women doubly marginalized and socially excluded. The present paper deals with the age hierarchy along with the gender hierarchy from socio-cultural and literary perspectives. It is a search for possible answers to some prominent questions like whether ageing women have different issues, problems and limitations in comparison to younger generation. It also aims to make ageing woman visible in the literary and feminist discourses. Four plays have been selected for the analysis in the present paper: Mangalam by Polie Sengupta, Harvest by Manjula Padmanabhan, Tripurari Sharma's Bahu and Aurat by Rasheed Jahan. The paper is divided into two parts: the first section is theoretical that deals with the discourses on gendered ageing and second is analytical, based on textual analysis of four selected plays with the portrayal of ageing in context.

Jeannette King calls women who are over fifty 'the invisible generation' in her book Discourses on Ageing in Fiction and Feminism: The Invisible Woman. She asserts that woman loses her identity after fifty because a woman's value has historically been determined by her reproductive ability, her beauty and sexuality. Thus the loss of youth amounts to the loss of identity. Older body, especially a female body after menopause, is seen as a pathological body, failed body and non-body stereotypically. The centrality of body in ageing needs to be questioned. She points out the absence of discourse on this issue in academia and tried to integrate the topics of ageing under feminist studies. She wrote, "It is almost impossible to find any heroines of Victorian literature who are older than 40, in spite of the prominent part played by older women in first-wave feminism" (King, 2013, p.xvii). King has analyzed the condition of ageing women having a western perspective.

Feminist critics of the first generation like Simone de Beauvoir, Betty Friedan and Germaine Greer have discussed the problems and issues connected with ageing. A significant aspect pointed out by Beauvoir is that elderly are socially marginalized. Woman's ageing body faces double objectification. However, Beauvoir has been criticized for having completely negative view of old age. For Betty Friedan and Greer, the identity of women must go beyond her sexual and biological role. Susan Sontag talks about the face-body dichotomy in her essay "The Double Standard of ageing" as she said that for centuries women have been forced by the patriarchal system (of course, women also participate in their own subordination) to base their success on their physical appearance which is called "the beauty myth" by Naomi Woolf. Thus her face becomes a sort of emblem, icon which cannot be changed or altered and in the older stage of life, her face becomes the subject to a continuous make up so that it appears unaltered. Instead of allowing oneself to age gracefully, people at large are culturally conditioned to fight against it either with cosmetic surgery, anti-ageing creams or hair dyes (Samiezade'-yazd, 2010). Betty Friedan critics the American obsession with the body and preservation of youth and exterior appearance through artificial methods such as cosmetics and plastic surgery in her book The Fountain of Age. The American science fiction film Surrogates (2009) is based on humans especially those who are ageing having the remote controlled humanoid fit and attractive robots through which they interact with society from the safety of their homes. In the movie the character of a wife Maggie who never comes outside her room and only interact with people even with her husband via her beautiful and attractive surrogate.

After the 1970s in feminist studies, a new awareness came to discuss the problems of female ageing as Marylin Pearsall defines old age as the most stigmatized stage in a woman's life cycle. Though feminist writers were 
highly influential in the development of the literature on the body, exploring themes around reproduction, selffashioning, bodily exclusion, denigration, and desire, they were initially reluctant to engage with the aging body. Work on the body in its early manifestations both within feminism and more widely was marked by a focus on younger, sexier bodies, by concern with the transgressive themes of queer theory and with fashionable and media-focused questions of representation. Ageing was not part of this. As Arber and Ginn (1991) argue, the exclusion of older women from feminist writing itself reflected the gerontophobia of the wider culture. This situation has just begun to alter. Within western culture, to emphasize the bodily can be to reduce or lessen an individual, and there has been a long history of misogynistic discourse in which women are denigrated by reducing them to their bodily characteristics. Dwelling on the bodily in relation to old women is thus seen as doubly deplorable. Foremost among the cultural critics is Gullette (1997) in her classic account Declining to Decline. Gullette argues that we are aged by culture rather than by our bodies. Culture is saturated with concepts of age and aging. Dominant culture teaches us to feel bad about aging and to start this early, reading our bodies anxiously for signs of decay and decline. We breathe in this toxicity daily. Cole (1993), in his history of aging, makes a similar point concerning the narrowing of the meanings of the body in old age that has occurred in the wake of the rise of modern science-based medicine. This has replaced the polysemic ones of the past in which the last stages of life were valued and significant by virtue of their nearness to death, by being more close to human reality yet living bravely and in which there were still possibilities of narratives of spiritual development. Vollendungsroman is an important term in this context which is coined by literary critic Constance Rook in 1992. If Bildungsroman refers to the novels where the protagonist is coming of age, growing, developing towards adulthood and maturity, Vollendungsroman is the 'novel of completion' which is concentrated on the last stage of life. It is also based on the principle that the psyche of the elderly is in continuous movement, it is not the last stoppage of life but a progress towards a mature journey of knowing oneself.

\section{II}

The present paper not only aims to make ageing female figures visible in the literary and feminist discourses but also to question the negative and disappointing portrayal of ageing women in literature, in Indian context especially and to serve the purpose, four plays have been selected: Mangalam by Polie Sengupta, Harvest by Manjula Padmanabhan, Tripurari Sharma's Bahu and Rasheed Jahan's Aurat. Apart from these writers, there are few other well-known literary figures in the canon of Indian literature who have shown their concern over the issue of old age for example, Premchand's wrote a short story called Budhi Kaki, Bhishm Sahni's story Chief ki Dawat, Tripurari Sharma's play Lado Masi having female protagonists who are in their 60s.

How does woman exist in her 60s or after, is not the subject of study in the present paper but how is she represented in literature. The critical studies suggest that ageing is represented largely in two ways: either they are lost, invisible generation in the text (who are hardly visible or underdeveloped portrayal) or they are represented as an incompetent, nagging, dependent persona. Old age is considered as an age of boredom, loneliness and decline. The present paper exposes the binary portrayal of ageing woman and ageism, conventionally practiced in the society. The paper analyses how the characters experience and negotiate with the world whereas trapped in more than one marginalised category at the same time.

An aged woman is taken as a burden in a family. She is considered as not even an object of desire. After spending decades of working, living, nourishing, caring for others, she is subjected to poverty, loss of dignity, abuse, economic and emotional depravations. Ageing is both a biological as well as a social construct. They struggle to adapt the changes taking place in their physical bodies and also in their social relationships. Emotional insecurity: void in life, loss of spouse, friends, and relatives, bodily limitations, limited mobility, the cultural bias against ageing are some of the major problems related to ageing in India. Aged widows are particularly vulnerable to subjugation and social exclusion.

In Manjula Padmanabhan's play Harvest published in 1998 the character of an old woman Indumati Prakash called "MA" is of special interest in this context. Throughout the text, she is addressed as "MA" except at one 
place where her name was asked for certain formalities by the guards. MA represents an ageing gendered body who belongs to a third world country hence, triply marginalized as a woman, aged and as part of the third world from a lower middle class family. The play is set in a single room apartment of a lower-middle class and in a humble locality of urban area. Forty families are living in the same building and all share a single toilet which clearly suggests the miserable condition of people in the area who struggle hard for their basic requirements every day. In the same building, one of the rooms is inhabited by Om Prakash and his family, his mother Mrs Indumati Prakash, his wife Jaya and Jeetu, his brother.

The character of Ma in the play represents the gendered ageing body who is questionably asserting her presence with her harsh voice and words full of complaints and curse for others. She was asked by Om to "keep quiet" and pretend not to understand anything on the arrival of guards (who came to check about the family of Om who has become an organ donor due to poverty and unemployment) as she is reduced to her old body, someone who is considered as incapable of making rational conversations. Ageing is equated not to the maturity but with a series of lacks: the lack of rationality and understanding. An ageing body is taken as a pathological body, a nonbody, neither a subject nor an object of sexual desire or someone needed to pay attention. Hence, an uneducated lower middle-class woman and a widow Mrs. Indumati Prakash, completely dependent on her son for support now, she is reduced to mere a baggage of responsibility. Finally, she finds complete escape from the real world and its everyday affairs and hurdles in the self-contained Video Couch which is provided by Om's Organ-owner from the US, the First World. In the end, MA stops her physical-spatial movements completely, surrendering herself to the Video Couch and fixes herself like a dead body by getting her locked in a trunk shaped box. As an ageing woman, Macdonald notes, "All my life in a man's world, I was a problem because I was a woman; now I am a problem in a woman's world because I am a 65-year-old woman" (Pohl, 1993, p.202).

The character of Ma in the play Harvest is represented, to some extent, in the popular Indian image of a motherin-law who is always found as complaining, abusing, questioning, monitoring, doubtful, diplomatic, selfcentred, interested in neighbour's affairs etc. She is so much conditioned in her role that her character is named "Ma" and her actual name Mrs Indumati Prakash is mentioned in the play only when the guards and agents ask to identify her. The ageing body of a woman is a typecast in the role of cultural transmitter and Ma seems to perform the same in the play as she gave lessons to Jaya to be a good wife. The image of an Indian woman is glorified and worshipped traditionally in the role of mothering but when it comes to choose one between her role of mother and her duty as the protector of custom, tradition and familial honour, she is culturally expected to advocate in favour of family honour and rejects motherhood. Ma is represented in the same way as a caricature in the play. Ma hates Jeetu for his profession (a male prostitute) and even denies accepting him as her son. She had been complaining against Om also till she hears that he has finally got a job. Poverty makes her insensitive to the extent that instead of getting surprised and angry with Om's decision of selling his organs (seeing organ selling as a prosperous job!) she was rather happy hearing that they will become rich. She finds temporary escape in watching TV from the corporeal reality and ageing. Gradually she gets totally disconnected to the realities around her and absorbed in the TV programmes. Jeetu's organ transplant and blindness (forcefully), distress among her family members did not affect her. The virtual world becomes a high parameter for her to judge, to experience and examine her socio-physical realities. The virtual becomes the ideal which was more real than the reality for her. In one of the scenes, she describes a TV programme called Happy Families to Jaya and suggests her to watch and learn from it. Therefore, the play presents a futuristic and dystopian world, presenting the limits of human misery where the characters are looking, not for solutions, but for their individual escapes and way to survival.

Mangalam is Poile Sengupta's first play and it won a special prize in the Hindu-Madras Players playscripts competition in 1993. It was first performed on 14 January 1994 and the role of Thangam (the old widow) was performed by Poile Sengupta herself in the play. The playwright has mentioned in the introduction of the play that "It is about family politics, seen through the perspective of women" (Sengupta, 2010, p.1). Simone de Beauvoir's famous statement 'One is not born a woman; one becomes one' is rightly depicted in Thangam's 
character in the play Mangalam. In patriarchy, it is the man who has 'power over' the others but woman also participate in the nourishing and keeping the patriarchal structure intact for example, Thangam in the play is the advocate of customary rules of patriarchy. In the first Act (which is a play within the play), Thangam is portrayed as an elderly widow with the shaved head who is always dressed in white. She is always anxious about her niece Chitra's marriage. She is rude to Revathy, her daughter-in-law and maintains a traditional hostile relationship with her. However, Thangam is a strong woman who is bold enough to speak against the injustice happened to her sister Mangalam who died being a victim of domestic violence. She was not threatened by (Mangalam's husband) Dorai's warnings and abused him. Dorai completely dislikes her presence in his house. In the act two, Thangam is presented as modern, educated and sensible. When Nari mentioned to Sreeni about their college pledge to marry their children together, Thangam sharply responded, "We can't plan our children's lives, Nari. Not any more. Their choices have to be their own" (Sengupta, 2010, p.60). Ah the end, Thangam decides to leave her husband Sreeni when she came to know about his extra-marital affairs unlike Mangalam (in Act One) who kept silent even after knowing about her husband's affairs and allowed all, physical and mental tortures against her by her husband.

Toril Moi rightly asserts that "The fact that women often enact the roles of patriarchy has prescribed for them does not prove that patriarchal analysis is right" (Hall, 2004, p.98) and anybody can justify it under the shed. The feminist historian Gerda Lerner answered that women themselves participated in their own subordination because they had been deprived of education for long and economic dependence also made them to practice and participate in the oppression of women themselves (Nielsen, 1987, p.229).

Tripurari Sharma's play Bahu was originally written in Hindi in 1979 and the writer herself translated the play in English as Daughter-in-Law. In the play as in the society at large, the female characters are identified by their role in their family: mother, daughter-in-law, aunt etc. The play is set in a village of Punjab that is moving towards development around the 1960s (Sharma, 2013, p.308). The following conversation among women reveals enough the condition of women in the village:

Women: But which man here does not have another? Big mansions take big strides.

The moon too has marks. But you were his woman (wife) to keep as he fancied. Not for you to say! A man is a man, his heart hangs in a hundred places!

Daughter-in-law: (Drained of all emotions) My mother said the same to me. Married five years hence, I came here only now. A clear heart, tied to the birdle, I stepped in here. But his didn't match mine and to be with a false man was beyond me.

Mother: He's gone. Even then she's not quenched. The witch's appetite knows no end. (Sharma, 2013, p.314)

The play Daughter-in-Law (Bahu) is focused on the title figure and the role of mother, the old woman, represents a typecast and it is underdeveloped.

Rasheed Jahan's play Aurat was published in 1937, originally written in Urdu. It was translated and recollected by A. R. Manzar and Tutun Mukherjee. In the play, the character of Mamani (Fatima's maternal uncle's wife) is interesting. She lived in abroad with her husband for few years and she always wears sari which is sinful according to Islamic rules to abandon the Islamic dress, said Atiqullah. For Fatima, it was unbearable to see her husband bringing second wife to her home just because she was not able to give him a child. She shared her problems with her Mamani when she came to meet Fatima and as expected, Mamani had nothing to console her. Rather Mamani said, "In real life, what can a woman observing strict purdah achieve without the help of a protector or a man beside her?" (Jahan, 2005, p.531). She discourages Fatima to take the help of court in any way. She cries on women's miserable situation at large, proving Freudian statement that "anatomy is destiny": 
that a woman's body is always gendered and it decides her fate and destiny as if there is nothing beyond 'biological'. Feminists of second wave feminism after the 1960s had criticized Freud's theory. Although the play Aurat has particularly an old backdrop (1937) the portrayed of ageing woman has always been stereotyped in literature.

\section{Conclusion}

Ageing poses twin challenges. First is to ensure care and protection of elderly so that they can lead a healthy, productive and dignified life and the second is to look at older person as partners in progress rather than as a burden on society. To live with dignity is their basic human right of which they are deprived to a larger extent. "Old age becomes a type of cultural trap built on myths that are difficult to remove from cultural belief system" (Wilinska, 2012, p.292). In fact, ageing is not only a physical factor but a social, cultural and psychological entity as well. Monika Wilinska adds further that people respond to and actively construct their visions of old age and ageing and to experience ageing is to be present within those "narrative spaces" (2012, p.292). And the narratives, the constructed images affect the reality too since the narratives and images work as an agency in constructing identities.

The ageing generation could be the 'intellectual companions' of younger people. An educated ageing woman can be 'think tank' for her coming generation. After ageing, woman's identity in the figure of the grandmother, who is capable of transmitting a historic memory, values which last and pervade the new generations become important, especially in the Indian context. For many feminists, the grandmother becomes the symbolic mother and incarnates both the figure of the great mother and the genealogical transmission of knowledge. The figure of the grandmother as 'story teller', also dealt with by Marina Warner in her essays and short stories, reassesses the oral tradition and the transmission between generations of an ancient knowledge related to a folklore tradition possessed by every nation. Ageing is a process and the space for successful ageing can be constructed through awareness and conscious choices.

\section{References}

Calasanti, T., 2006, Ageism and Feminism: From "Et Cetera" to Center. NWSA Journal, 18(1), pp. 13-30.

de Beauvoir, S., 1970, The coming of age. Print ed. New York: W. W. Norton \& Company.

Friedan, B., 1993, The Fountain of Age. Print ed. New York: Simon and Schuster.

Gullette, M. M., 1997. Declining to Decline: Cultural Combat and the Politics of the Midlife. print ed. US: University Press of Virginia.

Hall, D. E., 2004. Subjectivity. Print ed. New York: Routledge.

Jahan, R., 2005. Woman (Aurat). In: T. Mukherjee, ed. Staging Resistance: Plays by women in Translation. New Delhi: Oxford University Press, pp. 517-538.

Jeannette, K., 2013. Discourses of Ageing in Fiction and Feminism: The Invisible Woman. Print ed. London: Palgrave Macmillan.

Marinova, D., 2013. Cultural Alienation in the Ageing Person. Psychological Thought, 6(2), pp. 264-282.

Moore, S., 2009. No matter what I did I would still end up in the same position': age as a factor defining older women's experience of labour market participation. Work Employment and Society, 23(4), pp. 655-671.

Mowl, G., 2000. The Ageing Body and the Homespace. Area, 32(2), pp. 189-197.

Nielsen, T. H., 1987. The Creation of Patriarchy. Vol. 1. Women and History by Gerda Lerner. Acta Sociologica, 30(2), pp. 229-232.

Padmanabhan, M., 1998. Harvest. Print ed. New Delhi: Kali for Women.

Pohl, J. M., 1993. Ageism within Feminism. IMAGE: Journal of Nursing Scholarship, 25(3), pp. 199-203. 
Samiezade'-yazd, S., 2010. Ageism is a Feminist Issue. Feministing Community. [Online]

Available at: http://feministing.com/2010/07/27/ageism-is-a-feminist-issue/.

Scott-Maxwell, F., 1979. The Measure of My Days. Printed ed. US: Penguin Books.

Sengupta, P., 2010. “Mangalam.” Women Centre Stage: The Dramatist and the Play. print ed. New Delhi: Routledge.

Singh, A. \& Mukherjee, T. T., 2013. Gender, Space and Resistance: Women and Theatre in India. In: T. Sharma, ed. Daughter-In-Law (Bahu). print ed. New Delhi: D.K. Printworld, pp. 306-365.

Sontag, S., 1972. The Double Standard of Ageing. Saturday Review of The Society, pp. 29-39.

Thomas, R., 1993. The Journey of Life: A Cultural History of Aging in America. Print ed. US: CUP.

Waxman, B. F., 1997. To live in the Centre of the Moment: Literary Autobiographies of Aging. Print ed. USA: University of Virginia Press.

Wilinska, M., 2012. Is there as place for Ageing Subject? Stories of Ageing at the University of the Third Age in Poland. Sociology, 46(2), pp. 290-304.

Wolf, N., 1991. The Beauty Myth: How Images of Beauty are used Against Women. reprint ed. UK: Vintage.

Woodward, K., 2017. Rereading Simone de Beauvoir's The Coming of Age. Age Culture Humanities, Issue 3. 